\title{
PRAKTIK INCOME SMOOTHING PADA PERUSAHAAN SEKTOR PERTANIAN DI BEI
}

\author{
Sumani \\ sumani@unej.ac.id \\ Ahmad Roziq \\ Widyastuti Annisa \\ Fakultas Ekomomi dan Bisnis, Universitas Jember
}

\begin{abstract}
The research objective is to examine the practice of income smoothing with several explanatory variables, namely: cash holding, political cost, profitability, and the board of commissioners. There are indications that agricultural sector companies are doing income smoothing. The population is all agricultural sector companies listed on the IDX for the 2014-2019 period, with a purposive sampling technique, the number of samples used was 16 agricultural sector companies. Furthermore, the number of observed data was 96 data (6 years of observation in 16 agricultural sector companies). Methods of data analysis using logistic regression with $a=5 \%$ and $a=10 \%$. The results showed that cash holding and profitability had no significant effect on income smoothing practices, both at $a=5 \%$ and $a=10 \%$, but the political cost had a significant positive effect and the board of commissioners had a significant negative effect on income smoothing practices in agricultural sector companies. The implication of income smoothing practice with several explanatory variables can maintain the stability of the company's financial performance and will become an attraction for interested parties, however, income smoothing practise must go through supervision and consider some of the advice given by the board of commissioners.
\end{abstract}

Key words: cash holding, board of commissioners, income smoothing, political cost, profitability.

\begin{abstract}
ABSTRAK
Tujuan penelitian adalah untuk menelaah praktik income smoothing dengan beberapa variabel penjelas, yaitu: cash holding, political cost, profitabilitas, dan dewan komisaris. Populasi adalah seluruh perusahaan sektor pertanian yang terdaftar di BEI periode 2014-2019, dengan teknik purposive sampling, maka jumlah sampel yang digunakan adalah 16 perusahaan sektor pertanian. Selanjutnya jumlah data yang diobservasi sebanyak 96 data (6 tahun pengamatan pada 16 perusahaan sektor pertanian). Metode analisis data dengan regresi logistik dengan $\alpha=5 \%$ dan $\alpha=10 \%$. Hasil penelitian bahwa cash holding dan profitabilitas berpengaruh tidak signifikan terhadap praktik income smoothing, baik pada $\alpha=5 \%$ dan $\alpha=10 \%$, namun political cost berpengaruh signifikan positif dan dewan komisaris berpengaruh signifikan negatif terhadap praktik income smoothing perusahaan sektor pertanian. Implikasi praktik income smoothing dengan beberapa variabel penjelas dapat menjaga stabiitas kinerja keuangan perusahaan dan akan menjadi daya tarik bagi pihak-pihak yang bekepentingan, namun praktik income smoothing harus melalui pengawasan dan mempertimbangkan beberapa nasihat yang diberikan dewan komisaris.
\end{abstract}

Kata kunci: cash holding, dewan komisaris, income smoothing, political cost, profitabilitas.

\section{PENDAHULUAN}

Laporan keuangan merupakan sumber informasi atas kondisi keuangan suatu perusahaan yang diperlukan untuk memenuhi kebutuhan berbagai pihak, baik internal maupun eksternal perusahaan. Pada prinsip- nya setiap investor sangat membutuhkan informasi tentang keuntungan yang diperoleh perusahaan, hal ini akan memotivasi pihak manajer untuk merekayasa pelaporan agar laba yang dicatatkan kelihatannya menjadi lebih menarik. Laba merupakan 
salah satu informasi penting yang terkandung dalam laporan keuangan.

Statement of Financial Concepts (SFAC) No.1. telah menegaskan urgensi informasi laba, yaitu memiliki peran utama yaitu laporan keuangan dapat menilai kinerja manajemen, selain itu juga membantu manajemen dalam meramalkan kemampuan laba dengan tepat. Di sisi lain laporan keuangan dapat memberikan manfaat untuk memprediksi tingkat risiko dalam melaksanakan investasi atau kredit. Selanjutnya menurut Beattie et al., (1994) manfaat untuk memprediksikan tingkat risiko dalam melaksanakan investasi atau kredit tersebut terkadang kurang dirasakannya karena pihak investor dan kreditor lebih terfokus pada perolehan laba tanpa memperhatikan prosedur atau tahapan yang digunakan oleh manajemen dalam menghasilkan laba tersebut. Bagi investor urgensi informasi laba yaitu untuk mendorong manajemen untuk melakukan tindakan dengan orientasi pada peningkatan nilai perusahaan yang ditunjukkan dengan peningkatan laba. Penjelasan lebih lanjut dari Hwihanus dan Qurba, (2010), kondisi tersebut (investor dan kreditor lebih terfokus pada perolehan laba) disebabkan karena angka laba yang stabil akan menunjukkan keberhasilan kinerja manajemen di mata para investor. Berdasarkan uraian diatas, manajemen mengupayakan cara atau strategi bagaimana agar laba perusahaan menjadi stabil dari waktu ke waktu. Salah satu cara yang sering digunakan adalah dengan merekayasa data pembentuk laba oleh pihak manajemen, hal ini yang dikenal dengan istilah manajemen laba.

Menurut Scott (2006), manajemen laba dapat dilakukan dengan empat cara, yaitu: taking a bath, income minimization, income maximazation, dan income smoothing. Praktik income smoothing merupakan sebagian kebijakan atau tindakan manjemen dengan tujuan untuk meningkatkan market returns (Michelson et al., 2000), sebab berisi informasi terkait harga saham dimasa datang (Salehi dan Manesh, 2011). Praktik income smoothing merupakan kejadian yang sudah biasa terjadi sebagai usaha manajemen untuk mengurangi fluktuasi laba yang dilaporkan (Nazir dan Suzanti, 2002). Belkaoui (2007) menyatakan income smoothing sebagai proses normalisasi laba yang disengaja untuk meraih tujuan perusahaan yang diinginkan. Selanjutnya menurut Amanza dan Rahardjo (2012) income smoothing, meliputi: natural smoothing (perataan alami) dan intentional smoothing (perataan yang disengaja). Tindakan income smoothing jika dilakukan dengan cara yang tidak wajar akan dapat menimbulkan adanya kesalahan pengambilan keputusan bagi investor dan pihak-pihak yang berkepentingan (Jatiningrum, 2000).

Agency theory menunjukkan bahwa konsep income smoothing terjadi apabila semua pihak memiliki motivasi untuk melakukan aktivitas atau kegiatan berdasarkan keinginannya sendiri-sendiri sehingga hal ini seringkali memunculkan konflik antara prinsipal dan agen. Jensen dan Meckling (1976) menjelaskan bahwa dalam teori keagenan, konflik kepentingan antara pihak principal dan agen sering terjadi karena pihak-pihak eksternal perusahaan seperti kreditor dan investor merasakan memiliki jumlah informasi yang lebih sedikit dan kurang berkualitas dibandingkan dengan pihak internal (manajer). Teori keagenan (agency theory) merupakan kontrak antara agent dan principal, dimana setiap individu memiliki kepentingan masing-masing dan akan termotivasi untuk mengambil keputusan yang akan menguntungkan dirinya sendiri. Principal dan agent yang memiliki kepentingan masing-masing menyebabkan munculnya konflik kepentingan antara pemegang saham dan manajemen. Prasetya (2013) principal seringkali menggunakan laporan keuangan atau informasi akuntansi sebagai acuan dalam mengukur kinerja dan pemberian imbalan manajer. Hal ini menyebabkan munculnya disfunctional behavior (perilaku tidak seperti pada umumnya atau semestinya) yang dilakukan manajer melalui praktik perataan laba agar laporan keuangan 
dapat terlihat lebih baik dari kondisi riil (sebenarnya). Hubungan principal dan agent sering ditentukan oleh angka akuntansi sehingga memacu agent untuk memikirkan bagaimana angka akuntansi dapat digunakan sebagai sarana memaksimalkan kepentingannya (Fricilia dan Lukman, 2015).

Hal tersebut sebenarnya akan memunculkan asimetri informasi. Menurut Chen (2008) bahwa manajemen yang memiliki akses informasi perusahaan yang lebih banyak dan jika merasa informasi tersebut merugikan kepentingannya, maka manajemen akan melakukan praktik income smoothing. Manajemen melakukan income smoothinng dengan beberapa alasan, diantarannya: kinerja perusahaan meningkat (Cohen dan Zarowin, 2010); strategi manajer dalam menghadapi perubahan lingkungan bisnis (Kuo et al., 2014); perubahan tarif pajak (Joosten, 2012; Akbari et al., 2018); perubahan peraturan atau regulasi ( $\mathrm{Yu}$ et al., 2006); kompetisi dalam pasar produk (Laksmana dan Yang, 2014); sifat oportunis yaitu untuk memaksimalkan perolehan bonus (Cohen dan Zarowin, 2010) dan memenuhi ekspektasi para analis (Gunny, 2010).

Praktik income smoothing terjadi pada perusahaan sektor pertanian yang terdaftar di BEI. Hal ini dilihat dari penelitian terdahulu menggunakan Indeks Eckel seperti Gambar 1 berikut:

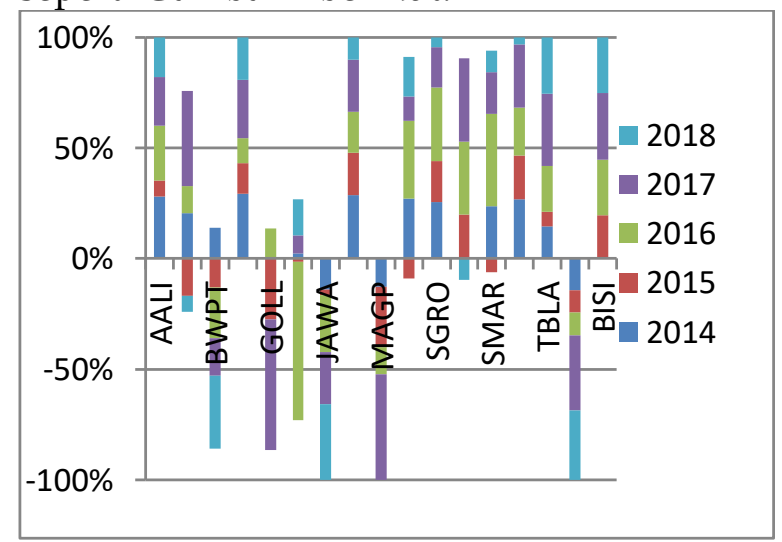

\section{Gambar 1 \\ Laba Bersih Sektor Pertanian di BEI 2014-2018}

Sumber: data yang diolah Rahel, 2019.

Berdasarkan Gambar 1 tersebut me- nunjukkan bahwa laba bersih pada beberapa perusahaan sektor pertanian yang terdaftar di BEI cenderung stabil tiap tahunnya dari tahun 2014-2018. Kondisi ini memungkinkan adanya indikasi perusahaan sektor pertanian melakukan praktik income smoothing (Rahel, 2019).

Banyak faktor sebagai pembentuk atau mempengaruhi perataan laba. Penelitian Mohammadi et al., (2012) menguji pengaruh cash holding terhadap income smoothing. Hasil penelitian Cendy dan Fuad (2013) bahwa cash holding, profitabilitas dan nilai perusahaan sebagai determinan atau faktor yang mempengaruhi perataan laba. Selain itu Akhoondnejad, Garkaz dan M. Ahoorvarzi (2013) political cost juga merupakan faktor yang mempengaruhi perataan laba.

Penelitian ini menggunakan variabel cash holding, political cost, profitabilitas dan corporate governance sebagai variabel yang mempengaruhi perataan laba, karena berdasarkan hasil beberapa penelitian sebelumnya tampaknya variabel tersebut sering digunakan sebagai determinan atau pembentuk perataan laba dan hasilnya masih belum konsisten antara penelitian yang satu dengan yang lainnya (gap research). Selain itu agar pengguna laporan keuangan lebih berfokus terhadap laba daripada item laporan keuangan lainnya.

Income smoothing dihitung dengan Indeks Eckel, sebab pendekatan ini memiliki kelebihan, yaitu memberikan hasil objektif dan adanya pemisah yang jelas. Corporate governance diproksikan dengan komposisi dewan komisaris yang berperan memonitor praktik income smoothing sehingga dapat meminimalkan timbulnya agency problem. Tujuan dalam penelitian yaitu menelaah praktik income smoothing dengan variabel penjelas cash holding, political cost, profitabilitas dan dewan komisaris dalam upaya normalisasi laba untuk meningkatkan market return.

\section{TINJAUAN TEORETIS} Agency Theory (Teori Keagenan)

Eisenhardt (1989) menjelaskan bahwa 
teori agensi menggunakan tiga asumsi sifat dasar manusia yang meliputi: (1) manusia memiliki daya pikir terbatas mengenai persepsi masa mendatang (bounded rationality) yang menjadi sumber variasi model pengambilan keputusan; (2) manusia pada umumnya mementingkan diri sendiri (self interest) sehingga akan berusaha sekuat tenaga untuk mencapai kepentingannya, meskipun harus dengan mengorbankan kepentingan orang lain atau yang lainnya; dan (3) manusia selalu menghindari risiko (risk averse) sehingga mereka berupaya untuk mencari informasi sebanyak mungkin guna mendapatkan keputusan terbaik yang risikonya paling dapat mereka tanggung. Berdasarkan asumsi sifat dasar manusia tersebut, maka dapat disimpulkan bahwa manusia kemungkinan besar akan bertindak berdasarkan sifat opportunistik, yaitu berusaha untuk mengutamakan kepentingan pribadi mereka. Selanjutnya, ketika manajemen bertindak sebagai agen maka seharusnya bertanggungjawab mengoptimalkan keuntungan pemilik dan bertindak untuk kepentingan pemilik namun sebaliknya mereka justru termotivasi untuk mendapatkan keuntungan pribadinya, misalnya memperoleh kompensasi yang lebih tinggi.

Konflik kepentingan yang ada dalam teori keagenan, menurut Jensen dan Meckling (1976) terjadi apabila manajer memiliki sejumlah informasi berkualitas yang jauh lebih banyak dibandingkan pihak stakeholder perusahaan yaitu kreditor dan investor. Kondisi semacam ini dikenal dengan istilah asimetri informasi. Asimetri informasi dapat dilihat pada saat manajer memiliki informasi internal perusahaan lebih banyak dan mempunyai akses informasi dengan lebih cepat dibandingkan pihak stakeholder eksternal. Dengan demikian, manajemen yang merupakan agen dapat memiliki lebih banyak informasi dan memanfaatkan informasi yang tidak dapat diketahui oleh principal demi memaksimalkan kepentingannya sendiri.

Sifat lebih mementingkan kebutuhan agen merupakan "penyakit" yang dikenal dengan istilah moral hazard dan adverse selection. Moral hazard merupakan perilaku manajer yang memanipulasi informasi sebagai upaya manajer untuk mengutamakan kepentingan diri sendiri sehingga tidak sesuai tuntunan moral etika yang benar. Disisi lain, adverse selection merupakan perilaku manajer dalam mengelola informasi yang boleh dan tidak boleh diungkapkan. Pada akhirnya, manajer akan melakukan pemilihan informasi yang sejalan dengan kepentingannya dan menyembunyikan informasi lainnya kepada external meskipun informasi tersebut masuk kategori informasi penting.

Selanjutnya, agency relationship merupakan kontrak dimana satu atau beberapa orang (yang disebut owners atau pemegang saham) menunjuk seorang lainnya dalam hal ini kemudian orang yang ditunjuk disebut sebagai pengurus atau manajer untuk melakukan beberapa pekerjaan atas nama owners. Pekerjaan yang dimaksud termasuk pendelegasian wewenang guna mengambil keputusan. Sehingga manajemen diharapkan mampu mengoptimalkan sumber daya yang ada di perusahaan tersebut dengan optimal. Utility maximizer's dapat terjadi apabila kedua belah pihak mampu memaksimalkan perannya. Hal ini menjadi alasan yang kuat, karena pada umumnya pemilik mempunyai welfare motives yang bersifat jangka panjang, namun sebaliknya manajemen lebih bersifat jangka pendek. Seringkali manajemen cenderung memaksimalkan profit jangka pendek dan mengabaikan sustainability keuntungan jangka panjang. Pemilik dapat menetapkan insentif yang sesuai bagi manajemen sebagai upaya dalam membatasi dan mengurangi berbagai kemungkinan, yaitu dengan mengeluarkan biaya monitoring dalam bentuk gaji. Monitoring cost menjadi pengendali manajemen agar dapat memaksimalkan kesejahteraan pemilik, meskipun keputusan manajemen dalam prakteknya bisa saja berbeda dengan harapan pemilik (Jensen dan Meckling, 1976).

Corporate governance merupakan efekti- 
vitas yang dilakukan dengan tujuan meminimalkan terjadinya konflik keagenan. Khususnya pada penekanan mekanisme legal yang dapat mencegah terjadinya eksproriarsi pada pemegang saham. Corporate governance adalah elemen kunci dalam meningkatkan efisiensi ekonomis. Corporate governance merupakan serangkaian hubungan antara manajemen perusahaan, dewan komisaris, pemegang saham dan stakeholders lainnya. Corporate governance juga merupakan struktur yang dapat memfasilitasi penentuan sasaran-sasaran suatu perusahaan, dan dapat pula sebagai sarana dalam menentukan metode monitoring kinerja (Darmawaty dan Rika, 2004).

\section{Manajemen Laba dan Perataan Laba (Income Smoothing)}

Sulistyanto (2008) menyatakan bahwa manajemen laba dapat ditinjau dari dua aspek, yaitu pelaporan keuangan dan kontraktual. Aspek pelaporan keuangan dapat menunjukkan bahwa manajer menggunakan manajemen laba untuk memenuhi ramalan analis laba sebagai usaha dalam menghindari rusaknya reputasi dan reaksi negatif atas harga saham yang terjadi secara cepat pada saat ekspektasi investor tidak tercapai. Sehingga, jalan yang diambil manajer adalah melakukan pencatatan writeoff yang berlebihan atau memfokuskan pada penambahan laba lain selain laba bersih, yang disebut "pro-forma earnings". Aspek kedua adalah dengan melaporkan kecenderungan pola laba yang stabil dan bertumbuh dalam periode waktu tertentu. Dalam konteks pasar modal yang efisien, hal tersebut menunjukkan informasi internal manajemen. Dengan demikian, manajemen laba adalah cara untuk mengkomunikasikan informasi internal kepada pihak investor. Perataan laba menjadi hal yang menarik, hal ini disebabkan karena manajemen laba merupakan hal yang bermanfaat berdasarkan perspektif pelaporan keuangan.

Perataan laba pada dasarnya melibatkan pilihan yang disengaja dari perubahan waktu transaksi yang dapat memengaruhi arus kas untuk mengendalikan peristiwa ekonomi yang terjadi. Upaya yang dapat dilakukan adalah dengan memilih dan merubah waktu pembelian, sewa produksi, investasi, penjualan, penganggaran modal, penelitian dan pengembangan, periklanan serta keputusan-keputusan yang lainnya. Hal ini merupakan suatu pilihan atas pelaksanaan bisnis yang secara sengaja dapat merubah arus kas sebuah perusahaan pada arah peredaman fluktuasi atas pendapatan. Berbagai bentuk upaya pengendalian peristiwa ekonomi yang terjadi dan usaha membuat sebuah peristiwa dengan tujuan memegaruhi arus kas serta meratakan laba. Upaya yang dilakukan oleh manajemen dalam perataan riil bertujuan untuk merubah keputusan produksi maupun investasi perusahaan pada akhir periode, berdasarkan atas pengetahuan terhadap bagaimana kinerja perusahaan (Riahi dan Belkaoui, 2011).

Konflik yang terjadi antara manajer dengan pemegang saham dapat menyebabkan keinginan manajemen untuk mengendalikan kas di perusahaan. Manajemen yang merupakan agen dalam perusahaan akan mengambil sebuah keputusan untuk mempertahankan kontinuitas operasional perusahaannya. Kinerja manajer dapat direpresentasikan dari perilaku manajer pada saat melakukan penjagaan agar kas diperusahaan tetap stabil. Manajer akan menggunakan cash holding dengan tujuan untuk meminimalkan pendanaan eksternal maupun operasional perusahaan. Dengan demikian cash holding dapat bersifat likuid, jangka pendek serta mudah dijadikan kas dalam jumlah tertentu tanpa mengalami perubahan nilai yang berarti. Cash holding merupakan hal yang mudah dikendalikan manajer yang dapat menimbulkan motivasi manajer untuk melakukan perbuatan atas kepentingan pribadi. Hal ini dapat meningkatkan praktik income smoothing oleh karena karakteristik jumlah kas yang tersedia dalam perusahaan. Thalebnia dan Darvish (2012) mengemukakan bahwa perusahaan yang memiliki aliran kas-nya 
bersifat bebas dapat menghadapi permasalahan agensi yang tinggi sehingga mengakibatkan manajer semakin terdorong untuk melakukan perbuatan terkait praktik income smoothing

Pelaksanaan manajemen laba yang berlebihan dapat mengurangi manfaat yang sebenarnya dari adanya laporan keuangan bagi para investor, terutama jika manajer melakukan manajemen laba secara oportunistik dan tidak diungkapkan secara penuh. Perspektif kontraktual menunjukkan bahwa manajer menerapkan manajemen laba dengan tujuan melindungi perusahaan atas konsekuensi dari peristiwa yang tidak tercantum dalam kontrak yang kaku dan tidak lengkap. Tujuan kedua adalah untuk mencapai kompensasi yang efisien. Hal ini dikarenakan kontrak kompensasi manajerial dapat memungkinkan peluang terjadinya manajemen laba atas dasar pertimbangan bahwa biaya tinggi dapat digunakan untuk mengeliminasi manajemen laba.

Manajemen laba juga berkontribusi terhadap motivasi manajer dalam meningkatkan kinerjanya. Manajer dapat menggunakan manajemen laba untuk menstabilkan kompensasi dalam periode waktu tertentu, sehingga dapat mengurangi terjadinya risiko kompensasi. Namun demikian, manajer sebaiknya menghindari risiko tertentu pada saat mereka bekerja keras untuk perusahaan.

Metode yang dilakukan manajer dalam menerapkan manajemen laba yaitu dengan memilih kebijakan akuntansi tertentu yang sesuai dengan tujuan manajer. Metode berikutnya adalah melakukan tindakan riil yang berpengaruh pada peningkatan laba, misalnya pemotongan biaya penelitian dan pengembangan.

Urgensi informasi laba dapat mendorong manajemen untuk meningkatkan performa laba yang lebih baik melalui mekanisme manajemen laba. Manajemen laba dapat diartikan sebagai upaya manajer untuk mempengaruhi informasi-informasi dalam laporan keuangan dengan tujuan agar supaya stakeholder tidak mengetahui kinerja dan kondisi perusahaan secara akurat
(Sulistyanto, 2008). Oleh karena itu, tujuan utama manajemen laba yaitu untuk mengkamuflase, sehingga wajar jika manajemen memiliki persepsi negatif sehingga termasuk kategori opportunistic perspective of earnings management.

Sulistyanto (2008) menyatakan bahwa manajemen laba adalah campur tangan atau intervensi pada proses penyusunan pelaporan keuangan dari eksternal, yang bertujuan memperoleh keuntungan pribadi. Model atau teknik dalam melakukan manajemen laba bermacam-macam caranya, yang paling sering (umum) adalah melalui rekayasa akrual. Strategi selain itu adalah memanipulasi aktivitas riil. Dengan demikian, kedua strategi tersebut memerlukan keahlian khusus di bidang akuntansi, manajemen, dan keuangan sehingga dikenal dengan istilah kejahatan kerah putih.

Pola manajemen laba memiliki pola yang beragam tergantung pada tujuannya. Salah satu pola manajemen laba yaitu perataan laba. Perataan laba merupakan salah satu usaha yang dilakukan manjemen untuk meningkatkan market returns (Michelson et al., 2000). Market returns dapat terkait erat dengan kinerja perusahaan berdasarkan perspektif pasar modal. Investor pada umumnya menyukai laba yang bertumbuh secara gradual dan berkelanjutan. Dalam perspektif jangka panjang, investor akan menyadari bahwa return perusahaan yang berkualitas dapat diperoleh dari laba yang bertumbuh secara positif, meskipun pertumbuhannya lambat.

Hal tersebut menjadi alasan manajer untuk mengusahakan agar laba yang dilaporkan terus bertumbuh sesuai dengan harapan investor dengan tujuan saham perusahaan akan mendapat penilaian yang bagus. Berdasarkan pendapat Beidleman (1973) dalam Rahmawati dan Muid (2012) tujuan perataan laba adalah untuk mengurangi fluktuasi pada pelaporan laba serta untuk mengurangi risiko agar harga sekuritas menjadi tinggi dan menarik perhatian pasar.

Ashari et al., (1994) menyatakan bahwa 
perataan laba adalah tanda dari manjemen dalam memilih kebijakan akuntansi untuk meminimalkan fluktuasi yang berpengaruh pada kinerja perusahaan di masa datang. Perataan laba merupakan pengurangan fluktuasi dari periode ke periode melalui pemindahan earnings dari periode puncak untuk mengurangi ketercapaian perusahaan. Pada dasarnya, tindakan tersebut dapat diperkenankan, namun yang menjadi titik permasalahannya adalah pada niat manajer. Pada saat manajer memiliki niat untuk mengelabui pihak eksternal, maka tindakan yang sebenarnya diperkenankan tersebut pada akhirnya secara hakikatnya adalah tindakan kriminal. Disatu sisi, manajemen laba berbasis kebijakan akuntansi, terdapat hal-hal yang perlu diperhatikan, yaitu pilihan kebijakan akuntansi yang terbagi menjadi dua, yaitu kebijakan akuntansi per se dan kebijakan akuntansi diskresionari akrual. Kebijakan pemilihan penggunaan metode amortisasi garis lurus atau saldo menurun serta kebijakan pengakuan pendapatan. Di sisi lain, kebijakan akuntansi diskresioneri akrual sebagi misal penentuan kerugian penjualan kredit, biaya garansi, penilaian persediaan, waktu serta jumlah item yang persistensinya rendah seperti writeoff maupun penentuan restrukturisasi.

Konsekuensi kedua adalah manajemen laba berbasis kebijakan akuntansi (iron law) adalah accrual reverse atau akrual yang berkebalikan. Maksud dari iron law adalah manajer dapat mengatur laba agar meningkat dengan jumlah yang melebihi kemampuan, sehingga manajer akan melakukan kebijakan akuntansi yang berkebalikan pada periode berikutnya. Namun demikian, kondisi ini dapat mengakibatkan penurunan laba relatif dibandingkan peningkatan laba periode saat ini. Jika kinerja perusahaan buruk, maka upaya penerapan manajemen laba tidak dapat secara langsung dilakukan. Dengan demikian, manajemen laba menjadi hal yang baik jika tidak dilakukan sebagai sarana misleading atau fraudulent reporting. Akan tetapi, jika manajemen laba tetap dilakukan, dengan kondisi perusahaan yang buruk, maka hal itu dapat disebut sebagai kesalahan manajemen laba (earnings mismanagement).

Konsekuensi accrual reverse ini menggambarkan urgensi penelitian tentang manajemen laba dengan metode multipleperiod. Dengan begitu penelitian ini dapat memberikan pemahaman yang lebih baik tentang seberapa kuat kecenderungan perusahaan untuk melakukan manajemen laba dan seberapa kuat pasar modal serta pasar tenaga kerja mengendalikan tindakan manajemen laba oportunistik.

\section{Dewan Komisaris}

Dewan komisaris dibentuk sebagai salah satu mekanisme yang digunakan dalam memonitor kinerja manajer. Berdasarkan Surat Keputusan Bursa Efek Jakarta (BEJ) Nomor: Kep-315/BEJ/06-2000 yang mengharuskan perusahaan terdaftar di bursa efek harus memiliki dewan komisaris yang dapat memonitor perusahaan sehingga tercipta Good Corporate Governance di Indonesia

Berdasarkan hukum yang ada, dewan komisaris berfungsi untuk melakukan pengawasan maupun memberikan nasehat kepada direksi. Pemantauan dewan komisaris terhadap direksi, berguna untuk memastikan bahwa direksi telah menindaklanjuti semua temuan audit dan rekomendasi dari satuan kerja audit intern (SKAI), auditor eksternal, maupun hasil pengawasan otoritas lain. Dewan Komisaris harus mampu mengawasi dan memenuhi kepentingan seluruh stakeholders berdasarkan atas azas kesetaraan, mengarahkan, dan memantau, serta mengevaluasi pelaksanaan kebijakan strategis perusahaan.

Perusahaan yang berbentuk perseroan terbatas, dapat melakukan penunjukkan auditor yang dilakukan oleh manajemen puncak. Namun demikian, kebebasan auditor akan berkurang jika dipandang dari sudut pemegang saham, yaitu dewan komisaris. Sebagaimana pendapat Mulyadi (2002) terkait dengan dewan komisaris yaitu: "Dewan komisaris adalah wakil pemegang 
saham dalam perusahaan yang berbadan hukum Perseroan Terbatas. Dewan komisaris ini berfungsi dalam mengawasi pengelolaan data perusahaan yang di kelola oleh manajemen (direksi). Oleh karena itu, Dewan Komisaris yang aktif menjalankan fungsinya dengan baik, dapat mencegah pengendalian yang terlalu banyak di dalam manajemen (direksi).

\section{Cash Holding dan Income Smoothing}

Jensen dan Meckling (1976) menunjukkan bahwa manajemen sebagai agen akan mengambil keputusan guna mempertahankan kelangsungan operasional perusahaan. Efektivitas pengambilan keputusan, salah satunya dengan menjaga kenaikan kas di perusahaan dengan stabil. Cash holding dilakukan oleh manajer untuk meminimalkan penggunaan pendanaan eksternal maupun operasional perusahaan. Oleh karena cash holding yang bersifat likuid, jangka pendek serta mudah dijadikan kas dalam jumlah tertentu tanpa mengalami perubahan nilai yang berarti. Sehingga hal ini dapat meningkatkan praktik income smoothing karena adanya karakteristik jumlah kas yang tersedia dalam perusahaan. Secara teoritis, ada berbagai motif untuk memegang kas dalam transaksi dan motif kehati-hatian yang biasanya dianggap sebagai motif agensi (Jensen, 1986). Penjelasan tersebut sesuai dengan penelitian yang dilakukan Cendy dan Fuad (2013); Mohammadi et al. (2012); Sarwinda dan Afriyenti (2015) menunjukkan bahwa cash holding berpengaruh terhadap income smoothing. Dengan demikian rumusan hipotesis sebagai berikut:

$\mathrm{H}_{1}$ : Cash holding berpengaruh positif signifikan terhadap praktik income smoothing

\section{Political Cost dan Income Smoothing}

Keinginan dalam meminimalkan risiko politik atau political cost hypothesis menjadi salah yang memotivasi manajer untuk melakukan perataan laba. Biaya ini mencakup seluruh biaya (transfer kekayaan) yang harus ditanggung oleh perusahaan terkait dengan keputusan-keputusan politis seperti pajak, regulasi, subsidi pemerintah, tarif, dan antitrust, serta tuntutan buruh dan lain sebagainya (Watts dan Zimmerman, 1986). Akhoondnejad et al., (2013) menyatakan bahwa political cost merupakan salah satu faktor yang mempengaruhi income smoothing. Bagi perusahaan, intensitas politik sering berkaitan dengan ukuran perusahaan (Watts dan Zimmerman, 1986). Perusahaan yang berskala besar memiliki kemungkinan menghadapi biaya politis yang lebih besar dibanding perusahaan kecil. Perusahaan yang berskala besar akan berusaha menurunkan laba untuk mengurangi biaya politis (Belkaoui, 2007). Perusahaan besar biasanya lebih diawasi oleh pemerintah dan masyarakat. Jika perusahaan skala besar mempunyai laba yang tinggi secara relatif permanen, maka pemerintah dapat terdorong untuk meminta layanan publik yang lebih tinggi dan menaikkan pajak kepada perusahaan (Calvin, 2012). Selanjutnya dapat dibangun hipotesis sebagai berikut:

$\mathrm{H}_{2}$ : Political cost berpengaruh positif signifikan terhadap praktik income smoothing

\section{Profitabilitas dan Income Smoothing}

Profitabilitas merupakan rasio yang digunakan untuk memberi penilaian perusahaan dalam mencari keuntungan pada periode tertentu (Wulandari dan Zulhaimi, 2017). Manajemen perusahaan yang profitabilitasnya tinggi cenderung akan melakukan income smoothing guna mengetahui kemampuan di masa depan (Prabayanti dan Yasa, 2011). Sebenarnya praktik income smoothing tidak hanya pada saat profitabilitas tinggi, namun profitabilitas yang turun juga dilakukan income smoothing agar tidak terjadi fluktuasi laba yang berlebihan. Penelitian Atarwaman (2011) membuktikan bahwa perusahaan yang melakukan tindakan income smoothing, proporsi tertingginya ada pada saat profitabilitas perusahaan tersebut tinggi. Sedangkan menurut Ashari 
et al. (1994) menyimpulkan bahwa perusahaan yang tingkat ROA rendah mempunyai kecenderungan yang lebih besar untuk meratakan labanya. Penelitian Cendy dan Fuad (2013); Oktyawati dan Agustia (2014) menegaskan bahwa proftabilitas berpengaruh positif signifkan terhadap income smoothing. Berdasarkan kajian tersebut dapat dihipotesiskan sebagai berikut:

$\mathrm{H}_{3}$ : Profitabilitas berpengaruh positif signifikan terhadap praktik income smoothing.

\section{Dewan Komisaris dan Income Smoothing}

Menurut Siallagan dan Machfoedz (2006) dewan komisaris berperan dalam pengawasan serta mencegah terjadinya income smoothing dan memastikan laporan keuangan disajikan secara lengkap dan dapat diandalkan. Keberadaan dewan komisaris menjadi sangat penting mengingat adanya kepentingan dari manajemen untuk melakukan manajemen laba yang berdampak pada kurangnya kepercayaan investor, sehingga dewan komisaris diperbolehkan untuk memiliki akses pada informasi perusahaan (Sochib, 2016). Dewan komisaris juga berperan meningkatkan kualitas laba dengan membatasi tingkat manajemen laba melalui fungsi monitoring atas laporan keuangan (Vafeas, 2000). Penelitian Handayani et al. (2016) dan Sugiarti (2017) bahwa dewan komisaris berpengaruh terhadap income smoothing. Dengan demikian rumusan hipotesis sebagai berikut:

$\mathrm{H}_{4}$ : Dewan komisaris berpengaruh negatif signifikan terhadap praktik income smoothing

Berdasarkan latar belakang, kajian teori dan penelitian terdahulu, maka kerangka konseptual yang dibangun dalam penelitian ini tersaji sebagaimana Gambar 2 berikut.

Gambar 2 tersebut menunjukkan arah korelasi variabel pembentuk atau penjelas, meliputi: cash holding, political cost, profitabilitas dan dewan komisaris terhadap income smoothing. Tujuan penelitian ini menelaah praktik income smooting dengan variabel penjelas cash holding, political cost, profitabilitas dan dewan komisaris dalam rangka normalisasi laba guna mencapai tujuan yang ditargetkan, baik maket return maupun harga saham diwaktu yang akan datang pada perusahaan sektor pertanian. Kondisi ini terbentuk karena praktik income smooting mengandung informasi tentang kinerja perusahaan yang baik.

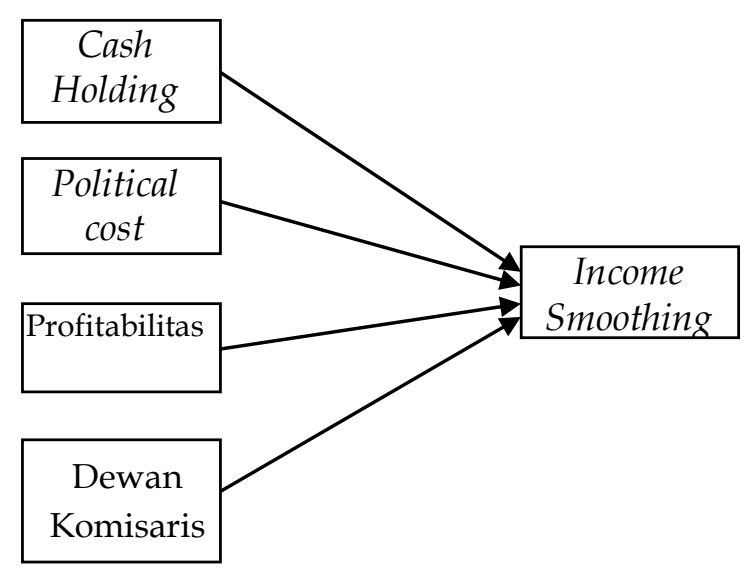

\section{Gambar 2 \\ Kerangka Konseptual}

\section{METODE PENELITIAN}

\section{Populasi dan Sampel}

Populasi dalam penelitian ini adalah sektor pertanian yang terdaftar di BEI periode 2014-2019, sebanyak 21 perusahaan. Pemilihan sampel dilakukan dengan teknik purposive sampling, dimana pemilihan sampel didasarkan pada kriteria tertentu. Berdasarkan kriteria tersebut, jumlah sampel penelitian sebanyak 16 perusahaan. Teknik analisis data dengan kombinasi data time series dan data cross section, yang sering disebut dengan data panel selama 6 tahun, dengan demikian jumlah pengamatan sebanyak 96 data (16 perusahaan X 6 tahun). Data yang digunakan adalah data sekunder, yang diperoleh dari laporan keuangan Tahun 2014-2019 dan telah dipublikasikan di Bursa Efek Indonesia (BEI) melalui web www.idx.co.id maupun di website resmi perusahaan. 
Tabel 1

Proses Pengambilan Sampel

\begin{tabular}{|c|c|}
\hline Kriteria Sampel & Jumlah \\
\hline $\begin{array}{l}\text { Perusahaan pertanian yang } \\
\text { terdaftar dan aktif di BEI sejak } \\
\text { tahun } 2014 \text { hingga tahun } 2019 .\end{array}$ & 21 \\
\hline $\begin{array}{l}\text { Perusahaan pertanian memi- } \\
\text { liki laporan keuangan lengkap } \\
\text { dan menyediakan data yang } \\
\text { sesuai dengan variabel pe- } \\
\text { nelitian selama periode 2014- } \\
2019 \text {. }\end{array}$ & (4) \\
\hline $\begin{array}{l}\text { Laporan keuangan yang tidak } \\
\text { disajikan dalam mata uang } \\
\text { rupiah }\end{array}$ & (1) \\
\hline $\begin{array}{l}\text { Perusahaan pertanian meng- } \\
\text { alami delisting }\end{array}$ & (0) \\
\hline $\begin{array}{l}\text { Jumlah perusahaan yang di- } \\
\text { jadikan obyek pengamatan }\end{array}$ & 16 \\
\hline
\end{tabular}

Hasil proses pengambilan sampel, maka ditentukan terdapat 16 perusahaan yang dijadikan pengamatan dari total keseluruhan perusahaan yang dijadikan pengamatan yaitu 21 perusahaan. Sampel yang digunakan ada 16 perusahaan didapat dari pengurangan perusahaan yang tidak memenuhi kriteria untuk dijadikan sampel atau pengamatan sebanyak 5 perusahaan. Perusahaan ini merupakan perusahaan sektor pertanian yang tidak memiliki laporan keuangan lengkap selama periode 2014-2019 sebanyak 4 perusahaan dan 1 perusahaan pertanian yang tidak menyajikan laporan keuangan dalam mata uang rupiah. Namun tidak ada perusahaan sektor pertanian yang mengalami delisting. Sehingga terdapat 16 perusahaan sektor pertanian tahun 20142019 yang dijadikan sampel data.

\section{Metode Analisis Data}

Variabel yang digunakan dalam penelitian ini dibagi menjadi dua macam yaitu: Variabel independen yang dipilih oleh peneliti untuk diuji dalam penelitian ini yaitu cash holding (caho), political cost (poco), profitabilitas (prof), dan dewan komisaris (deko). Variabel dependen yang dipilih oleh peneliti yaitu income smoothing (ismo), dengan menggunakan variabel dummy.

Tabel 2

Definisi Operasional dan Skala Pengukuran

\begin{tabular}{|c|c|c|c|}
\hline Variabel & Simbol & Definisi Operasional & Skala \\
\hline Income Smoothing & $\mathrm{Y}$ & $\begin{array}{l}\text { Tindakan manajemen per- } \\
\text { usahaan sektor pertanian untuk } \\
\text { menstabilkan laba secara di- } \\
\text { sengaja agar mencapai tujuan } \\
\text { perusahaan }\end{array}$ & Nominal \\
\hline Cash Holding & $\mathrm{X}_{1}$ & $\begin{array}{l}\text { Kemampuan perusahaan sektor } \\
\text { pertanian dalam memegang kas }\end{array}$ & Rasio \\
\hline Political Cost & $X_{2}$ & $\begin{array}{l}\text { Kemampuan perusahaan sektor } \\
\text { pertanian dalam melunasi } \\
\text { kewajiban biaya politik }\end{array}$ & Rasio \\
\hline Profitabilitas & $X_{3}$ & $\begin{array}{l}\text { Kemampuan perusahaan sektor } \\
\text { pertanian dalam mendapatkan } \\
\text { keuntungan }\end{array}$ & Rasio \\
\hline Dewan Komisaris & $\mathrm{X}_{4}$ & $\begin{array}{l}\text { Merupakan organ perusahaan } \\
\text { sektor pertanian yang ber- } \\
\text { tanggung jawab secara kolektif } \\
\text { untuk melakukan pengawasan } \\
\text { dan memberikan nasihat kepada } \\
\text { direksi. }\end{array}$ & Rasio \\
\hline
\end{tabular}


Tabel 3

Formulasi Variabel

\begin{tabular}{|c|c|c|c|}
\hline Variabel & Simbol & Rumus & Sumber \\
\hline Income Smoothing & Ismo (Y) & Indeks Eckel $=\frac{C V \Delta I}{C V \Delta S}$ & $\begin{array}{c}\text { Eckel, 1981; } \\
\text { Ashari et al., 1994 }\end{array}$ \\
\hline Cash Holding & Caho (X1) & $\frac{\text { Kas }+ \text { setara kas }}{\text { Total aset }}$ & $\begin{array}{l}\text { Mohammadi et } \\
\text { al., } 2012\end{array}$ \\
\hline Political Cost & Poco (X2) & Ln (Total Aset) & $\begin{array}{c}\text { Calvin, 2012; } \\
\text { Akhoondnejad et } \\
\text { al., } 2013\end{array}$ \\
\hline Profitabilitas & Prof (X3) & ROA $=\frac{\text { Laba bersih }}{\text { Total aset }} \times 100 \%$ & Ross et al., 2016 \\
\hline $\begin{array}{l}\text { Dewan } \\
\text { Komisaris }\end{array}$ & $\operatorname{Deco}(X 4)$ & $\frac{\text { Jumlah Komisaris Independen }}{\text { jumlah anggota komisaris }}$ & Sochib, 2016 \\
\hline
\end{tabular}

Sumber: Diolah

Income smoothing dapat diukur dengan Indeks Eckel (1981), peneliti membedakan perusahaan menjadi 2 yaitu kelompok perusahaan yang melakukan income smoothing dapat diberi nilai 1 (satu), dan kelompok perusahaan yang tidak melakukan income smoothing dapat diberi nilai 0 (nol).

Menurut Ashari et al. (1994) ada beberapa kelebihan yang dimiliki oleh indeks eckel yaitu, hasilnya objektif dan berdasarkan pada statistik dengan adanya pemisah yang jelas antara perusahaan yang melakukan income smoothing dan perusahaan yang tidak melakukan income smoothing. berikut:

Indeks Eckel dapat dirumuskan sebagai

$$
\text { Indeks Eckel }(1981)=\frac{C V \Delta I}{C V \Delta S}
$$

Nilai $C V \quad \Delta S$ dan $C V \quad \Delta I$ dapat dihitung dengan:

CV $\Delta S$ (Penjualan)dan CV $\Delta I($ Laba $)=$

Keterangan:

$$
\sqrt{\frac{\sum(\Delta X i-\Delta \bar{X})^{2}}{n-1}}: \Delta \bar{X}
$$

$\mathrm{CV}=$ Koefisien variasi variabel dimana standar deviasi dibagi dengan ratarata perubahan laba (I) atau pendapatan (S)

$\Delta S=$ Perubahan penjualan pada satu periode
$\Delta I \quad=$ Perubahan laba pada satu periode

$\Delta X i=$ Perubahan laba (I) atau penjualan (S)

$\Delta \bar{X} \quad=$ Rata-rata perubahan laba (I) atau penjualan (S)

$\mathrm{n} \quad=$ Banyaknya tahun yang diamati

Kriteria perusahaan yang menerapkan perataan laba yaitu: (1) perusahaan yang dianggap melakukan praktik perataan laba jika indeks perataan laba lebih kecil dari 1 (CV $\Delta \mathrm{S}>\mathrm{CV} \Delta \mathrm{I}$ ); (2) perusahaan yang dianggap tidak melakukan praktik perataan laba apabila indeksnya lebih besar sama dengan $1(\mathrm{CV} \Delta \mathrm{S} \leq \mathrm{CV} \Delta \mathrm{I})$

\section{Pengujian Regresi logistik}

Uji kelayakan model yang diuji dengan Hosmer and Lemeshow's Goodness of Fit Test. Model regresi dapat dikatakan layak menurut Hosmer and Lemeshow's Goodness of Fit Test berdasarkan keputusan; (a) jika nilai Hosmer and Lemeshow's Goodness of Fit Test statistics $\leq 0,05$, maka hipotesis nol ditolak, artinya ada perbedaan signifikan antara model dengan nilai observasinya, sehingga model dikatakan tidak baik, karena model tidak dapat memprediksi nilai observasinya; (b) Jika nilai Hosmer and Lemeshow's Goodness of Fit Test statistics $>0,05$, maka hipotesis nol diterima, berarti tidak ada perbedaan signifikan antara model dengan nilai observasinya, sehingga model dikatakan 
baik, karena model dapat memprediksi nilai observasinya (Ghozali, 2016).

Uji kelayakan seluruh model. Pengujian kelayakan model dalam uji regresi logistik terdapat beberapa tahapan yaitu:

a. Chi Square, merupakan penilaian model fit yang menggunakan Log Likelihood dengan cara membandingkan antara nilai $-2 \log$ Likelihood diawal (block number $=0$ ) dengan nilai -2 $\log$ Likelihood ditahap berikutnya (block number $=1$ ).

Selanjutnya model regresi dapat dikatakan fit, jika terjadi pengurangan antara angka -2 log likelihood (block number $=0-$ block number $=1$ )

b. Cox and Snell's $R$ Square, adalah koefisien Cox and Snell's $R$ Square dimana ukuran berdasarkan pada $R^{2}$ regresi linier berganda dengan menghasilkan nilai maksimum kurang dari satu. Model ini memiliki tujuan untuk mengetahui variabilitas variabel dependen yang dapat dijelaskan oleh variabel independen.

c. Nagelkerke's $R$ Square. Koefisien Nagelkerke's $R$ Square adalah modifikasi dari koefisien Cox and Snell's $R$ Square agar nilai maksimum dapat mecapai angka satu dan mempunyai rentang antara nol sampai dengan satu, sama seperti koefisien determinasi $\mathrm{R}^{2}$ pada regresi linear berganda. Semakin mendekasi nilai 1 (satu) maka model dianggap memiliki goodness of fit, sementara semakin mendekati 0 (nol) maka model semakin tidak bagus (Ghozali, 2016).

d. Model analisis data menggunakan regresi logistik, karena variabel terikat merupakan variabel dummy, dimana 0 (tidak melakukan praktik income smoothing) dan 1 (melakukan praktik income smoothing). Model regresi logistik ini menghasilkan nilai koefisien regresi dan signifikansi. Koefisien regresi pada tiap variabel akan diuji untuk menunjukkan bentuk hubungan antar variabel. Model regresi logistik pada penelitian ini dirumuskan sebagai berikut:

$$
\begin{array}{ll}
\begin{array}{ll}
\operatorname{Ln}\left(\frac{P}{1-P}\right)=\alpha+\beta_{1} \text { caho }+ & \beta_{2} \text { poco }+\beta_{3} \text { prof } \\
+ & \beta_{4} \text { deko }+\varepsilon
\end{array} \\
\begin{array}{ll}
\text { Keterangan: } & \\
\operatorname{Ln}\left(\frac{P}{1-P}\right) & =\text { Income Smoothing } \\
\begin{array}{l}
\alpha \\
\beta_{1}, \beta_{2}, \beta_{3}, \beta_{4}
\end{array} & =\text { Konstanta } \\
\text { regresi } & =\text { Nilai dari koefisien } \\
\varepsilon & =\text { Term of error }
\end{array}
\end{array}
$$

\section{Pengujian Hipotesis}

Uji statistik dilakukan untuk melihat sejauh mana pengaruh satu variabel independen secara individual terhadap variasi variabel dependen. Uji hipotesis dilakukan dengan menggunakan uji-t. Uji-t dilakukan dengan menguji apakah secara parsial variabel independen mampu menjelaskan variabel dependen (Ghozali, 2016) dirumuskan sebagai berikut:

$$
\mathrm{t}=\frac{\beta n}{S \beta n}
$$

Keterangan:

$$
\begin{array}{ll}
\mathrm{t} & =\text { Nilai pengujian } \\
\beta \mathrm{n} & =\text { Koefisien regresi variabel } \\
\mathrm{S} \beta \mathrm{n} & =\text { Standar eror variabel }
\end{array}
$$

Dengan menggunakan tingkatan signifikansi $(\alpha)$ sebesar $5 \%$ dan $10 \%$; apabila $t_{\text {hitung }}$ $>$ dari $\mathrm{t}_{\text {tabel }}$ maka $\mathrm{H}_{0}$ ditolak dan $\mathrm{H}_{\mathrm{a}}$ diterima dan sebaliknya jika $t_{\text {hitung }}<t_{\text {tabel }}$ maka $\mathrm{H}_{0}$ diterima dan $\mathrm{H}_{\mathrm{a}}$ ditolak. Selain itu apabila $p$ value $>\mathrm{a}$, maka $\mathrm{H}_{0}$ diterima dan $\mathrm{H}_{\mathrm{a}}$ ditolak, artinya variabel independenya secara parsial tidak berpengaruh signifikan terhadap income smoothing dan sebaliknya apabila $p$ value $\leq \mathrm{a}$, maka $\mathrm{H}_{0}$ ditolak dan $\mathrm{H}_{\mathrm{a}}$ diterima, artinya variabel independen secara parsial berpengaruh signifikan terhadap income smoothing.

\section{ANALISIS DAN PEMBAHASAN}

Analisis data dilakukan terhadap data yang tedapat pada official website BEI (Bursa Efek Indonesia) maupun website perusahaan, mengenai laporan tahunan dari perusahaan sektor pertanian yang sudah terpilih menjadi sampel. Analisis terhadap data penelitian 
laporan tahunan ini dilakukan untuk memperoleh hasil perhitungan dari income smoothing sebagai variabel dependen dan cash holding, political cost, profitabilitas dan dewan komisaris sebagai variabel independen dengan rumus yang telah dicantumkan sebelumnya. Analisis data ini dilakukan dengan menggunakan aplikasi SPSS 25 untuk melakukan uji regresi logistik.

Berdasarkan data yang telah diperoleh dari situs resmi BEI tahun 2014-2019 mengenai laba dan penjualan dari 16 perusahaan sektor pertanian yang terdaftar dan memenuhi krteria yang telah ditentukan, maka dapat diklasifikasikan berdasarkan Indeks Eckel. Berdasarkan indeks Eckel perusahaan yang melakukan income smoothing memiliki CV $\Delta I<C V \Delta S$, atau perusahaan yang tidak melakukan income smoothing memiliki CV $\Delta I>C V \Delta S$, dan diteliti selama 6 tahun mulai dari 2014-2019. Klasifikasinya seperti pada Tabel 4.

Tabel 4 menunjukkan bahwa perusahaan sektor pertanian periode 2014-2019 yang melakukan income smoothing sebanyak 12 perusahaan atau 72 data pengamatan atau $75 \%$ dari jumlah data seluruh perusahaan sampel dari tahun 2014-2019. Selanjutnya perusahaan yang tidak melakukan income smoothing sebanyak 4 perusahaan sektor pertanian atau 24 data pengamatan atau $25 \%$ dari jumlah data perusahaan dari tahun 2014-2019.

\section{Tabel 4}

Klasifikasi Data Perusahaan Income

Smoothing dan Perusahaan Bukan Income Smoothing

\begin{tabular}{clc}
\hline \hline No. & Status Perusahaan & Jumlah Data \\
\hline 1 & $\begin{array}{l}\text { Melakukan Income } \\
\text { smoothing }\end{array}$ & $72(12)$ \\
2 & $\begin{array}{l}\text { Tidak Melakukan } \\
\text { Income smoothing } \\
\text { Total }\end{array}$ & $96(16)$ \\
\hline
\end{tabular}

Sumber: Data diolah

\section{Statistik deskriptif}

Analisis statistik deskriptif digunakan untuk memberikan gambaran umum mengenai data yang diperoleh melalui nilai minimum, maksimum, mean dan standar deviasi

Tabel 5

Tabel Uji Statistik Deskriptif

\begin{tabular}{ccccc}
\hline \hline Variabel & Minimum & Maksimum & Rata-rata & Standar Deviasi \\
\hline Ismo (Y) & 0,00 & 1,00 & 0,76 & 0,428 \\
Caho (X1) & 0.00 & 0,229 & 0,049 & 0,05556 \\
Poco (X2) & 12.509 & 17,298 & 15,674 & 1,20624 \\
Prof (X3) & $-0,436$ & 0,154 & 0,0189 & 0,08037 \\
Deko (X4) & 0,250 & 0,667 & 0,3875 & 0,08482 \\
\hline
\end{tabular}

Sumber: Data diolah

Tabel 5 menunjukkan bahwa jumlah observasi dalam penelitian ini sebanyak 16 perusahaaan selama 6 tahun atau 96 pengamatan yang menunjukkan nilai minimum untuk income smoothing adalah 0 dan nilai maksimumnya adalah 1 dengan nilai rata-rata sebesar 0,76 serta standar deviasi sebesar 0,428.

Hasil uji statistik deskriptif menunjuk$\operatorname{kan} \mathrm{X}_{1}$ memiliki nilai minimumnya sebesar 0 dan nilai maksimumnya sebesar 0,229 . Nilai secara keseluruhan memiliki rata-rata 0,04959 dan ukuran standar deviasi sebesar 0,055563 . Nilai minimum pada $X_{1}$ dimiliki oleh perusahaan PT. Multi Agro Gemilang Plantation Tbk., dan nilai maksimum dimiliki oleh perusahaan PT. Sawit Sumbermas Sarana Tbk.

Hasil uji statistik deskriptif menunjukkan $\mathrm{X}_{2}$ memiliki nilai minimumnya sebesar 
12,509 dan nilai maksimumnya sebesar 17,298 . Nilai keseluruhan pada $X_{2}$ memiliki rata-rata sebesar 15,67433 dan ukuran standar deviasinya sebesar 1,206240. Pada uji $\mathrm{X}_{2}$ ini nilai minimum dimiliki oleh PT. Dharma Samudera Fishing Industries Tbk. sedangkan, nilai maksimumnya dimiliki oleh PT. Sawit Sumbermas Sarana Tbk. Hasil uji statistik deskriptif menunjukkan $X_{3}$ memiliki nilai minimum sebesar $-0,436$ dan nilai maksimumnya sebesar 0,154 . Nilai keseluruhan pada $X_{3}$ memiliki rata-rata sebesar 0,01890 dan ukuran standar deviasi sebesar 0,080373. Pada uji statistik deskriptif ini PT. Gozco Plantations Tbk. memiliki nilai minimum dari ke 80 sampel perusahaan dan PT. BISI International Tbk. memiliki nilai maksimum dari ke 80 sampel perusahaan.

Pada hasil uji statistik deskriptif menunjukkan $\mathrm{X}_{4}$ memiliki nilai minimum sebesar 0,25 dan nilai maksimumnya sebesar 0,667 . Nilai keseluruhan pada $X_{3}$ memiliki rata-rata sebesar 0,38735 dan ukuran standar deviasi sebesar 0,84824. Pada uji statistik deskriptif ini PT. Dharma Samudera Fishing Industries Tbk. memiliki nilai yang paling kecil (minimum) dan PT. Gozco Plantations Tbk memiliki nilai paling tinggi (maksimum). Pengujian Kelayakan Model (goodness of fit) ditunjukkan pada Tabel 6 berikut:

Tabel 6

Matriks Korelasi Parsial

\begin{tabular}{lcc}
\hline \multicolumn{1}{c}{ Variabel } & Koefisien regresi & Signifikansi \\
\hline Konstanta & 6,084 & 0,124 \\
\hline Caho (X1) & 2,642 & 0,642 \\
Poco (X2) & 0,561 & $0,053^{*}$ \\
Prof (X3) & $-9,060$ & 0,128 \\
Deko (X4) & $-10,888$ & $0,031^{* *}$ \\
-2 Log Likelihood (Blok =0) & 87,709 & \\
-2 Log Likelihood (Blok =1) & 87,709 & 0,293 \\
Hosmer and Lemeshow & 9,610 & \\
Cox and Snell R-Square & 0,132 & \\
Negelkerke R-Square & 0,199 & \\
\hline
\end{tabular}

Sumber: data diolah

$(*)=$ Signifikan $10 \%$

$(* *)=$ Signifikan $5 \%$

Uji regresi logistik dapat dilakukan dengan melihat ketepatan antara prediksi model logistik dengan data hasil pengamatan yang telah dilakukan dalam uji kelayakan model. Pengujian ini bertujuan mengetahui apakah ada kelemahan atas kesimpulan yang diperoleh dari model regresi logistik. Pengujian terhadap kelayakan model regresi logistik dilakukan dengan melakukan uji Hosmer and Lemeshow.

Pengujian terhadap kelayakan model regresi logistik dilakukan dengan melakukan uji Hosmer and Lemeshow. Tabel 6 menunjukkan bahwa nilai Hosmer and Lemeshow sebesar 9,610 dengan nilai signifikansi sebesar 0,293 yang berarti model fit karena memiliki signifikansi lebih dari $5 \%$.

\section{Uji Keseluruhan Model}

Pengujian terhadap keseluruhan model dilakukan dengan 3 (tiga) tahapan pengujian yaitu:

a) Chi Square

Berdasarkan tabel 6 uji regresi logistik indeks Eckel diketahui bahwa nilai -2 log likelihood pada model awal ( Blok $=0$ ) sebesar 87,709 dan nilai -2 log likelihood pada model akhir $($ Blok $=1$ ) sebesar 87,709 
jadi model regresi bersifat fit atau cocok dengan data.

b) Cox And Snell R-Square

Nilai Cox and Snell R-Square digunakan untuk menilai model fit yang diinterpretasikan sama dengan R-Square pada regresi berganda. Pada Tabel 6 diketahui nilai Cox And Snell R-Square sebesar 0,132 yang menandakan bahwa variabilitas variabel dependen dapat dijelakan oleh variabel independen sebesar $13,2 \%$. Jadi keragaman $13,2 \%$ dapat dijelaskan oleh model sedangkan sisanya diluar model.

c) Nilai Negelkerke R-Square

Nilai Negelkerke R-Square digunakan untuk menilai model fit yang diinterpretasikan sama dengan R-Square pada regresi berganda. Pada tabel 6 diketahui nilai Negelkerke R-Square sebesar 0,199 yang menandakan bahwa variabilitas variabel dependen mampu dijelaskan oleh variabel independen sebesar 19,9\%. Jadi keragaman $19,9 \%$ dapat dijelaskan oleh model sedangkan sisanya diluar model.

\section{Uji Regresi Logistik}

Tujuan dilakukan analisis uji regresi logistik adalah menguji dan menganalisis pengaruh variabel independen yang terdiri dari $X_{1}$ (cash holding), $X_{2}$ (political cost), $X_{3}$ (profitabilitas), dan $X_{4}$ (dewan komisioner) terhadap income smoothing (Y) pada perusahaan sektor pertanian di BEI. Variabel Y (income smoothing) pada penelitian diukur dengan variabel dummy. Berikut Tabel 7 menunjukkan hasil uji hipotesis dengan menggunakan uji regresi logistik:

Tabel 7

Hasil Uji Regresi Logistik

\begin{tabular}{cccccc}
\hline & B & S.E & Wald & $\begin{array}{c}\text { D } \\
\text { f }\end{array}$ & Sig \\
\hline $\mathrm{X}_{1}$ & 2,642 & 5,675 & 0,217 & 1 & 0,642 \\
$\mathrm{X}_{2}$ & 0,561 & 0,290 & 3,749 & 1 & 0,053 \\
$\mathrm{X}_{3}$ & $-9,060$ & 5,952 & 2,317 & 1 & 0,128 \\
$\mathrm{X}_{4}$ & $-10,888$ & 5,040 & 4,667 & 1 & 0,031 \\
$\begin{array}{c}\text { Cons } \\
\text { tant }\end{array}$ & 6,084 & 3,952 & 2,370 & 1 & 0,124 \\
\hline
\end{tabular}

Sumber: Data Diolah
Berdasarkan Tabel 7 dapat di bangun persamaan model regresi logistik sebagai berikut:

$$
\begin{gathered}
\operatorname{Ln}\left(\frac{P}{1-P}\right)=6,084+2,642 X_{1}+0,561 X_{2}- \\
9,060 X_{3}-10,888 X_{4}
\end{gathered}
$$

Dalam model tersebut menunjukkan bahwa arah korelasi cash holding dan political cost bertanda positif artinya apabila cash holding dan political cost mengalami peningkatan, maka perusahaan sektor pertanian termotivasi untuk mengadakan income smoothing, namun variabel profitabilitas dan dewan komisarisi arah korelasi bertanda negatif dengan income smoothing (apabila jumlah profitabilitas dan dewan komisaris mengaalami peningkatan, maka perusahan sektor pertanian tidak terdorong untuk melakukan income smoothing).

Tabel 7 menunjukkan hasil pengujian hipotesis, yaitu cash holding dan profitabilitas berpengaruh tidak signifikan terhadap income smoothing $\left(\mathrm{H}_{0}\right.$ diterima dan $\mathrm{Ha}$ ditolak). Namun, political cost berpengaruh positif signifikan terhadap income smoothing $(\alpha=10 \%)$ dan dewan komisaris berpengaruh negatif signifikan terhadap income smoothing $(\alpha=5 \%)$, berarti H0 ditolak dan Ha diterima.

\section{Cash Holding Berpengaruh Positif Signi- fikan terhadap Praktik Income Smoothing}

Hasil penelitian menunjukkan bahwa cash holding berpengaruh tidak signifikan terhadap praktik income smoothing (hipotesis ditolak). Fakta dilapangan menunjukkan beberapa perusahaan sektor pertanian memiliki sedikit aliran kas bebas, bahkan PT. Multi Agro Gemilang Plantation Tbk. Memiliki kas bebas sangat minimal (angka nol) dan yang tertinggi dimiliki perusahaan PT. Sawit Sumbermas Sarana Tbk., namun kedua perusahaan tersebut (baik yang memiliki kas bebas tinggi maupun rendah atau nol) terindikasi melakukan income smoothing. Sebenarnya terdapat implikasi yang dianggap kurang baik, khususnya bagi perusahaan pertanian yang tidak memiliki kas dan setara kas yang cukup yaitu berupa rendah- 
nya kinerja manajemen, hal ini disebabkan pihak manajemen tidak memiliki inovasi dan motivasi kerja dengan alasan tidak adanya ketersediaan dana yang likuid. Selanjutnya apabila perusahaan tersebut tidak memiliki cukup biaya untuk mendanai investasi baru perusahaan atau membayar deviden, maka perusahaan akan mengakumulasi kas (cash holding) atau bahkan melakukan pendanaan secara eksternal, yaitu berupa utang atau penerbitan saham baru. Hasil penelitian ini sesuai dengan penelitian Andriani (2012); Hutauruk (2013); Ayu dan Agung (2018) dan Riyadi (2018), menyatakan bahwa cash holding berpengaruh tidak signifikan terhadap income smooting. Sebaliknya, hasil penelitian ini bertentangan dengan penelitian Sar- winda dan Afriyenti (2015).

\section{Political Cost Berpengaruh Positif Signi- fikan terhadap Praktik Income Smoothing}

Hasil penelitian menunjukkan bahwa political cost berpengaruh positif signifikan terhadap income smoothing (hipotesis terbukti). Perusahaan yang berskala besar akan memiliki biaya politik yang besar pula, besarnya laba yang dilaporkan oleh perusahaan akan menjadi perhatian khusus berbagai elemen stakeholder (Godfrey et al., 2003). Perusahaan besar biasanya lebih diawasi oleh pemerintah dan masyarakat. Jika perusahaan skala besar mempunyai laba yang tinggi relatif permanen, maka pemerintah dapat terdorong untuk meminta layanan publik yang lebih tinggi dan menaikkan pajak kepada perusahaan (Calvin, 2012). Implikasinya perusahaan sektor pertanian yang memiliki ukuran aset yang besar akan sensitif terhadap risiko politik atau political cost, sehingga perusahaan tersebut cenderung melakukan praktik income smoothing melalui pengurangan laba atau dengan melaporkan beban atau biaya perusahaan diatas biaya atau beban yang sebenarnya (nilai perolehan) guna mengurangi biaya politik tersebut. Selain itu perusahaan sektor pertanian yang memiliki ukuran aset yang kecil misalkan PT. Dharma Samudera
Fishing Industries Tbk., cenderung tidak dikenakan biaya politik tinggi dengan alasan pemerintah berkepentingan untuk tumbuh dan bahkan memberikan incentif agar perusahaan tersebut tumbuh menjadi perusahaan besar.

Hasil penelitian mendukung penelitian Calvin (2012) yang menyatakan bahwa political cost berpengaruh terhadap praktik income smoothing. Sebaliknya, penelitian ini bertentangan dengan penelitian Sarwinda dan Afriyenti (2015).

\section{Profitabilitas Berpengaruh Positif Signi-} fikan terhadap Praktik Income Smoothing

Profitabilitas berpengaruh tidak signifikan terhadap income smoothing (hipotesis ditolak). Hal ini disebabkan bahwa pihak manajemen melakukan praktik income smoothing bukan karena profitabilitas (naik atau turun), tetapi lebih difokuskan pada target tujuan pihak manajer. Manajemen perusahaan tersebut tidak perlu melakukan income smoothing, karena kinerja perusahaannya telah dianggap baik dalam menjalankan tugasnya (Ayu dan Agung, 2018). Hal ini terbukti pada PT Gozco Plantations Tbk dengan nilai minimum -0,436 ditahun 2016 dan melakukan income smoothing, sedangkan pada PT BISI International Tbk dengan nilai maksimum 0,154 ditahun 2017, juga melakukan income smoothing. Hal ini menunjukkan besar kecilnya profitabilitas tidak menjamin perusahaan melakukan income smoothing. Implikasinya perusahaan kurang memiliki upaya untuk mengoptimalkan penggunaan total aset agar dapat meningkatkan laba bersih yang lebih tinggi, karena pada umumnya perusahaan yang profitabilitas tinggi cenderung melakukan income smooting dengan tujuan bahwa praktik tersebut mengandung informasi yang baik (good news) bagi investor atas market return perusahaan diwaktu yang akan datang.

Hasil penelitian ini sesuai dengan peneliti penelitian Masodah (2007) dan Sugiarti (2017) bahwa proftabilitas tidak berpengaruh terhadap income smoothing. 


\section{Dewan Komisaris Berpengaruh Negatif Signifikan terhadap Praktik Income Smoothing}

Dewan komisaris berpengaruh negatif signifikan terhadap income smoothing (hipotesis terbukti). Hal ini mengindikasikan bahwa semakin banyak anggota dewan komisaris, maka potensi untuk melakukan income smoothing semakin kecil. Menurut Sochib (2016) mengatakan bahwa dewan komisaris difokuskan untuk memonitor dari implementasi kebijakan direksi perusahaan. Dewan komisaris berperan untuk meminimalisir terjadinya permasalahan agensi antara dewan direksi dan pemegang saham. Dewan komisaris memegang peranan penting dalam mengarahkan strategi dan mengawasi jalannya perusahaan serta memastikan bahwa manajer benar-benar meningkatkan kinerja perusahaan sebagai bagian dari pencapaian tujuan perusahaan melalui praktik income smooting. Dengan demikian praktik income smoothing harus dimonitor oleh dewan komisaris agar dapat salah timbulnya agency problem. Implikasinya perusahaan sektor pertanian harus memperhatikan beberapa saran atau masukan (hasil monitoring) dari pihak dewan komisaris khususnya dalam praktik income smooting dan pihak manajemen harus memberikan akses pada dewan komisaris atas informasi perusahaan, baik informasi keuangan maupun informasi internal lainnya. Hasil penelitian ini mendukung penelitian (Weber, 2006; Rahel, 2019).

\section{SIMPULAN DAN SARAN}

Berdasarkan hasil penelitian dapat disimpulkan bahwa cash holding dan profitabilitas berpengaruh tidak signifikan terhadap praktik income smoothing perusahaan sector peranian di BEI, namun political cost berpengaruh positif signifikan dan dewan komisaris berpengaruh negatif signifikan terhadap praktik income smoothing pada perusahaan sektor pertanian. Hasil penelitian diharapkan menjadi pertimbangan pihak manajemen dalam praktek income smoothing, sehingga diharapkan dapat meningkatkan market return atau harga pasar saham perusahaan sektor pertanian di waktu yang akan datang. Selain itu agar keputusan praktik income smoothing lebih tepat lagi, maka pihak manajemen harus mempertimbangkan beberapa saran berdasarkan hasil monitoring dari dewan komisaris dan pihak manajemen juga memberikan akses informasi yang luas.

Namun penelitian ini memiliki keterbatasan yaitu Negelkerke R-Square hanya sebesar 19,9\%, artinya $80,1 \%$ dijelaskan diluar model. Dengan demikian bagi peneliti selanjutnya untuk memperpanjang periode analisis dan menambah variabel pembentuk atau penjelas praktek income smoothing pada perusahaan sektor pertanian, misalkan nilai perusahaan, leverage, ownership structure dan variabel makroekonomi (inflasi, kurs, pertumbuhan ekonomi, suku bunga dan lain-lain. Selain itu juga memasukkan variabel moderasi dan variabel control (ukuran perusahaan, lama prusahaan berdiri, dan lain lain).

\section{DAFTAR PUSTAKA}

Akbari, F., M. Salehi, dan M. A. B. Vlashani. 2018. The Relationship between Tax Avoidance and Firm Value with Income Smoothing: A Comparison Between Classical and Bayesian Econometric In Multilevel Models. International Journal of Organizational Analysis 27(1): 125-148.

Akhoondnejad, J., M. Garkaz, dan M. Ahoorvarzi. 2013. Political Cost Factors Affecting Income Smoothing Evindence from Tehran Stock Exchange (TSE). Journal of Contemporary Research in Business 5(2): 259-268.

Amanza, A. H. dan S. N. Rahardjo. 2012. Analisis Faktor-Faktor yang Mempengaruhi Praktik Perataan Laba (Income Smoothing). Diponegoro Journal of Accounting 1(1): 1-13.

Andriani, A. 2012. Bukti Empiris Perataan Laba dan Hubungan dengan Variable Fundamental, Good Corporate Governance \& kebijakan Dividen pada 
Perusahaan Perbankan yang terdaftar di Bursa Efek Indonesia. Skripsi.

Ashari, N., H. C. Koh, S. L. Tan, dan W. H. Wong. 1994. Factor Affecting Income Smoothing Amoong Listed Companies In Singapore. Journal Business \& Accounting Research. 24(96): 291-304.

Atarwaman, R. 2011. Analisis Pengaruh Ukuran Perusahaan, Profitabilitas, dan Kepemilikan Manajerial Terhadap Praktik Perataan Laba Yang Dilakukan oleh Perusahaan Manufaktur Pada Bursa Efek Indonesia (BEI). Jurnal Ilmu Ekonomi Advantege 2(2): 67-69.

Ayu, I. G. dan I. G. N. Agung. 2018. Pengaruh Cash Holding, Profitabilitas dan Ukuran Perusahaan Terhadap Perataan Laba Pada Perusahaan Properti di BEI. EJurnal Akuntansi. Uniersitas Udayana 23(3): 1682-1707.

Beattie, V., B. Stephen, E. David, J. Brian, M. Stuart, T. Dylan, dan T. Michael. 1994. Extraordinary Item and Income Smoothing: a Positive Accounting Approach. Journal of Business Finance and Accounting 21(6): 351-359.

Belkaoui, A. R. 2007. Accouting Theory. 5th Edition (Terjemahan). Salemba Empat. Jakarta.

Cendy, Y. P. dan Fuad. 2013. Pengaruh Cash Holding, Profitabilitas, Dan Nilai Perusahaan Terhadap Income Smoothing (Studi Empiris Pada Perusahaan yang Terdaftar Di Bursa Efek Indonesia Tahun 2009-2011). Diponegoro Journal of Accounting 3(1): 1-12.

Calvin, O. 2012. Faktor-Faktor yang Mempengaruhi Penerapan Konservatisme pada Perusahaan Manufaktur di BEI. Jurnal Ilmiah Mahasiswa Akuntansi 1(1): 36-42.

Chen, Y. R. 2008. Corporate Governance and Cash Holding: Listed New Economy versus Old Economy Firms. Journal Compilation Blackweel Publishing Ltd. 16(2): 430-442.

Cohen, D. A. dan P. Zarowin. 2010. AccrualBased and Real Earnings Management Activities around Seasoned Equity
Offerings. Journal of Accounting and Economics 50(1): 2-19.

Darmawaty, D. K. dan Rika G. R. 2004. Hubungan Corporate Governance dan Kinerja Perusahaan. Simposium Nasional Akuntansi VII, Denpasar-Bali.

Eckel, N. 1981. The Income Smoothing Hypothesis Revisited. Abacus 17(1): 2840.

Eisenhardt, K. 1989. Agency Theory: An Assesment and Review. Academy of Management Review 14: 57-74.

Fricilia, dan Lukman, Hendro. 2015. Analisis Faktor Yang Mempengaruhi Praktik Manajemen Laba pada Industri Perbankan Di Indonesia. Jurnal Akuntansi. XIX (1): 79-92.

Ghozali, I. 2016. Aplikasi Analisis Multivariate Dengan Program IBM SPSS 23. Edisi 8, Cetakan ke VIII. Badan Penerbit Universitas Diponegoro. Semarang.

Godfrey, J. M., P. Mather, dan A. Ramsay. 2003. Earnings and Impression Management in Financial Reports: The Case of CEO Changes. Financial Accounting and Auditing 39(1): 95-123.

Gunny, K. 2010. The Relation between Earnings Management Using Real Activities Manipulation and Future Performance: Evidence from Meeting Earnings Benchmarks. Contemporary Accounting Research. 27(3): 855-888.

Handayani, T. B., R. Andini, dan A. Oemar. 2016. Pengaruh Mekanisme Corporate Gavernance Terhadap Praktik Perataan Laba (Studi Kasus Pada Lembaga Keuangan Yang Terdaftar di BEI 20102014). Journal of Accounting 2(2): 1-10.

Hwihanus dan H. Qurba. 2010. FaktorFaktor yang Mempengaruhi Manajemen Laba pada Perusahaan Industri yang Terdaftar di BEI. Jurnal Ekonomi dan Bisnis 14(1): 1-6.

Hutauruk, F. W. M. 2013. Analisis Pengaruh Cash holdings Terhadap Praktik Income smoothing Pada Perusahaan Yang Terdaftar Di Bursa Efek Indonesia (BEI) Periode 2007-2011. Diponegoro Journal of Accounting 3(2): 9-19. 
Jatiningrum. 2000. Analisis Faktor-Faktor yang Berpengaruh terhadap Perataan Penghasilan atau Laba pada Perusahaan yang Terdaftar di BEJ. Jurnal Bisns dan Akuntansi 2(2): 145-155.

Jensen M. C. dan W. H. Meckling. 1976. Theory of the Firm: Managerial Behavior Agency Costs and Ownership Structure. Journal of Financial Economics 3(4): 305360.

Jensen, M. C. 1986. Agency Costs of Free Cash Flow, Corporate Finance and Takeovers. American Economic Review 76(2): 323-329.

Joosten, C. 2012. Real Earnings Management and Accrual-Based Earnings Management as Substitutes. Tesis. Department Accountancy Faculty of Economics and Business Studies Tilburg University. Tilburg.

Kuo, J. M., L. Ning, dan X. Song. 2014. The Real and Accrual-based Earnings Management Behaviors: Evidence from the Split Share Structure Reform in China. The International Journal of Accounting 49(1): 101-136.

Laksmana, I. dan Y. Yang. 2014. Product Market Competition and Earnings Management: Evidence from Discretionary Accruals and Real Activity Manipulation. Advances in Accounting 30(2): 263-275.

Masodah. 2007. Praktik Perataan Laba Sektor Industri Perbankan dan Lembaga Keuangan Lainnya dan Faktor yang Mempengaruhinya. Procceeding PESAT (Psikologi, Ekonomi, Sastra, Arsitek, E Sipil) 2. Auditorium Kampus Gunadarma, 21-22 Agustus 2007.

Michelson, S. E., J. J. Wagner, dan C. W. Wootton. 2000. The Relationship between the Smoothing of Reported Income and Risk Adjusted Returns. Journal of Economics and Finance 24(2): 141-159.

Mohammadi, S., M. M. Maharlouise, dan O. Mansouri. 2012. The Effect of Cash Holding on Income Smoothing. Journal of Contemporary Research in Business 4(2): 523-532.

Mulyadi. 2002. Auditing. Buku Dua, Edisi Ke Enam. Penerbit Salemba Empat. Jakarta.

Nazir, A. dan A. Suzanti. 2002. Analisis Pengaruh Perataan Laba Terhadap Risiko Pasar Saham dan Return Saham Perusahaan-Perusahaan Publik di Bursa Efek Jakarta. KOMPAK (5): 139-157.

Oktyawati, D. dan D. Agustia. 2014. Pengaruh Profitabilitas, Leverage, dan Nilai Perusahaan Terhadap Income Smoothing dan Return Saham Pada Perusahaan Manufaktur Yang Terdaftar Di Bursa Efek Indonesia (BEI). Jurnal Akuntansi \& Auditing 10(2): 195-214.

Prasetya. 2013. Pengaruh Ukuran Perusahaan, Profitabilitas, Financial Leverage, Klasifikasi KAP dan Likuiditas Terhadap Praktik Perataan Laba. Diponegoro Journal of Accounting 2(4): 1-7.

Prabayanti, N. P. A. dan G. W. Yasa. 2011. Perataan Laba (Income Smoothing) dan Analisis Faktor-Faktor yang Mempengaruhinya (Studi pada Perusahaan Manufaktur yang Terdaftar di Bursa Efek Indonesia). Jurnal Ilmiah Akuntansi dan Bisnis 6(1): 1-28.

Rahmawati, D. dan D. Muid. 2012. Analisis Faktor-Faktor yang Berpengaruh terhadap Praktik Perataan Laba (Studi pada Perusahaan Manufaktur yang Terdaftar di BEI Tahun 2007-2010). Diponegoro Journal of Accounting 1(1): 200-213.

Rahel, A. 2019. Analisis Faktor-Faktor Yang Berpengaruh Terhadap Praktik Perataan Laba. Juma UNSERA 1(1): 10-19.

Ross, S., R. Westerfeld, dan B. Jordan. 2016. Fundamentals of Corporate Finance. 11 th Edition. McGraw Hill. New York.

Riyadi, W. 2018. Pengaruh Cash Holding, Profitabilitas dan Nilai Perusahaan Terhadap Income Smoothing (Studi Empiris Pada Perusahaan Manufaktur yang Terdaftar di Bursa Efek Indonesia Tahun 2013-2015). Jurnal Ilmiah Manajemen dan Akuntansi 5(1): 58-61. 
Riahi, A. dan Belkaoui. 2011. Accounting Theory5th ed. Salemba Empat. Jakarta.

Salehi, M. dan N. B. Manesh. 2011. The Effect of Income Smoothing on The Informativeness of Stock Price Evidence From The Tehran Stock Exchange. Asian Journal on Quality 12(1): 80-90.

Sarwinda, P. dan M. Afriyenti. 2015. Pengaruh Cash Holding, Political Cost, dan Nilai Perusahaan Terhadap Tindakan Perataan Laba (Studi Empiris Pada Perusahaan Manufaktur Yang Terdaftar di BEI 2009-2013). Seminar Nasional Ekonomi Manajemen dan Akuntansi (SNE$M A)$. Fakultas Ekonomi Universitas Negeri Padang.

Scott, W. R. 2006. Financial Accounting Theory. Prentice Hall Inc. New Jersey.

Siallagan, H. dan M. Machfoedz. 2006. Mekanisme Corporate Governance, Kualitas Laba, dan Nilai Perusahaan. Proceeding Simposium Nasional Akuntansi IX 9(61): 23-26.

Sochib. 2016. Good Corporate Governance, Manajemen Laba dan Kinerja Keuangan. Edisi 1. Deepublish. Yogyakarta.

Sugiarti, R. 2017. Faktor-Faktor Rasio Keuangan dan Good Corporate Governance yang Mempengaruhi Praktik Perataan Laba. Jurnal Ilmu Akuntansi 10(2): 247260.

Sulistyanto, S. 2008. Manajemen Laba: Teori dan Model Empiris. PT. Gramedia Widiasarana Indonesia. Jakarta.
Surat Ketua Badan Pengawas Pasar Modal Nomor S-1595/PM/2000 tanggal 30 Juni 2000, Perihal Persetujuan Peraturan Pencatatan Efek PT Bursa Efek Jakarta.

Thalebnia, G. dan H. Darvish. 2012. Cash Holding on Income Smoothing: Evidence from Tehran Stock Exchange. Journal of Scientific Research 27(2): 54-63.

Vafeas, N. 2000. Board Structure and the Informativeness of Earning. Journal of Accounting and Public Policy 19(2): 139160.

Watts, R. L. dan J. L. Zimmerman. 1989. Positive Accounting Theory. Prentice Hall Inc. New Jersey.

Weber, M. 2006. Sensitivity of Executive Wealth to Stock Price, Corporate Governance and Earnings Management. Review of Accounting and Finance 5(4): 321-354.

Wulandari, S. dan H. Zulhaimi. 2017. Pengaruh Profitabilitas terhadap Corporate Social Responbility Pada Perusahaan Manufaktur Dan Jasa yang Terdaftar di Bursa Efek Indonesia. Jurnal Riset Akuntansi dan Keuangan 5(2): 1477-1488.

Yu, Q., B. Du, dan Q. Sun. 2006. Earnings Management at Rights Issues Thresholds-Evidence From China. Journal of Banking and Finance 30(12): 3453-3468. 